\title{
A multivariate assessment of the trophic state of a man-made reservoir in North Tunisia
}

\author{
Besma Zouabi Aloui ${ }^{1}$, Moncef Gueddari \\ ${ }^{1}$ Laboratory of Geochemistry and Environmental Geology, Department of Geology, Faculty of Sciences, University of Tunis el Manar, \\ 2092. Tunis, Tunisia, e-mail: besma.zouabi@inbmi.edunet.tn (corresponding author)
}

\begin{abstract}
In the present work, we attempt to test the applicability of common trophic state indices such as Carlson's index (1977), probability distribution diagrams of Vollenweider (1982), and fixed boundary systems of the OECD (1982) and of Nürnberg (1996) for evaluating the risk of eutrophication in the Sejnane reservoir in North Tunisia. The environmental parameters considered include monthly values of nutrients, chlorophyll $a$, Secchi transparency, turbidity and dissolved oxygen over a decade of monitoring from November 2001 through October 2011. To compile data and to identify key aspects of water quality, a multivariate technique as Principal Component Analysis was performed. Results show that productivity is limited by sedimentary turbidity, which contributes to decreasing water clarity and promotes the adsorption of phosphorus to suspended matter that decreases, indirectly, the bioavailability of nutrients. The Nürnberg model provides an accurate assessment of eutrophication with a clear internal coherence between self-indicators, and appears to be the most suitable way to evaluate eutrophication risk in the reservoir.
\end{abstract}

Key words: Trophic state, water quality, multivariate assessment, Sejnane reservoir, Tunisia

\section{Introduction}

Many of the freshwater lakes, streams, and reservoirs in North Africa suffer from nutrient enrichment resulting in increases in algal growth and in particular organic substances, which may cause water eutrophication particularly in stratified deep reservoirs (Benzha et al. 2005; Remini 2010). The main effects caused by eutrophication include impacts on water within the reservoir itself, on treatment plant control (flocculation, filtration and disinfection...) and distribution systems, and on water end-users (taste, odour and colour of waters). These effects can alter water quality and water supply (Chorus and Bartram 1999; Carmichael 2001).

In Tunisia, there was a growing concern about eutrophication especially for the Sidi Salem reservoir (Krause, 1984), which benefited from extensive research. Later, in 1988, Lars and Ulf ranked it as mesotrophic to eutrophic based on chlorophyll $a$ levels. In a previous study, Sternick (1991) based his observations on nutrient levels (nitrogen and phosphorus) and associate parameters (Secchi transparency, temperature, dissolved oxygen) and classified the Sidi Salem reser- voir as mesotrophic to eutrophic state. In a later study by Jean and Rejeb (1997), the authors studied 26 hill reservoirs in Central and Northern Tunisia and highlighted that no lake shows signs of eutrophication.

The focal objectives of the present study were to investigate key factors that control water quality in the Sejnane reservoir in Northern Tunisia and to provide a comprehensive assessment of its trophic state by evaluating the performance of common models such as TSI of Carlson (1977), probability distribution diagrams of Vollenweider (OECD 1982), and fixed boundary systems of the OECD (1982) and of Nürnberg (1996).

\section{Study area}

The Sejnane reservoir is located in the northeast of Tunisia at about $40 \mathrm{~km}$ west of Bizerte (Fig. 1). The boundaries of the study area extend from longitudes $9^{\circ} 29^{\prime} 00^{\prime \prime}$ to $9^{\circ} 22^{\prime} 30^{\prime \prime} \mathrm{E}$ and from latitudes $37^{\circ} 8^{\prime} 00^{\prime \prime}$ to $37^{\circ} 11^{\prime} 30^{\prime \prime} \mathrm{N}$. The reservoir is $35-40 \mathrm{~m}$ maximum in depth with a $7.35 \mathrm{~km}^{2}$ surface area and $122 \mathrm{Mm}^{3} \mathrm{ca}-$ pacity. The dam was constructed in the middle reaches 


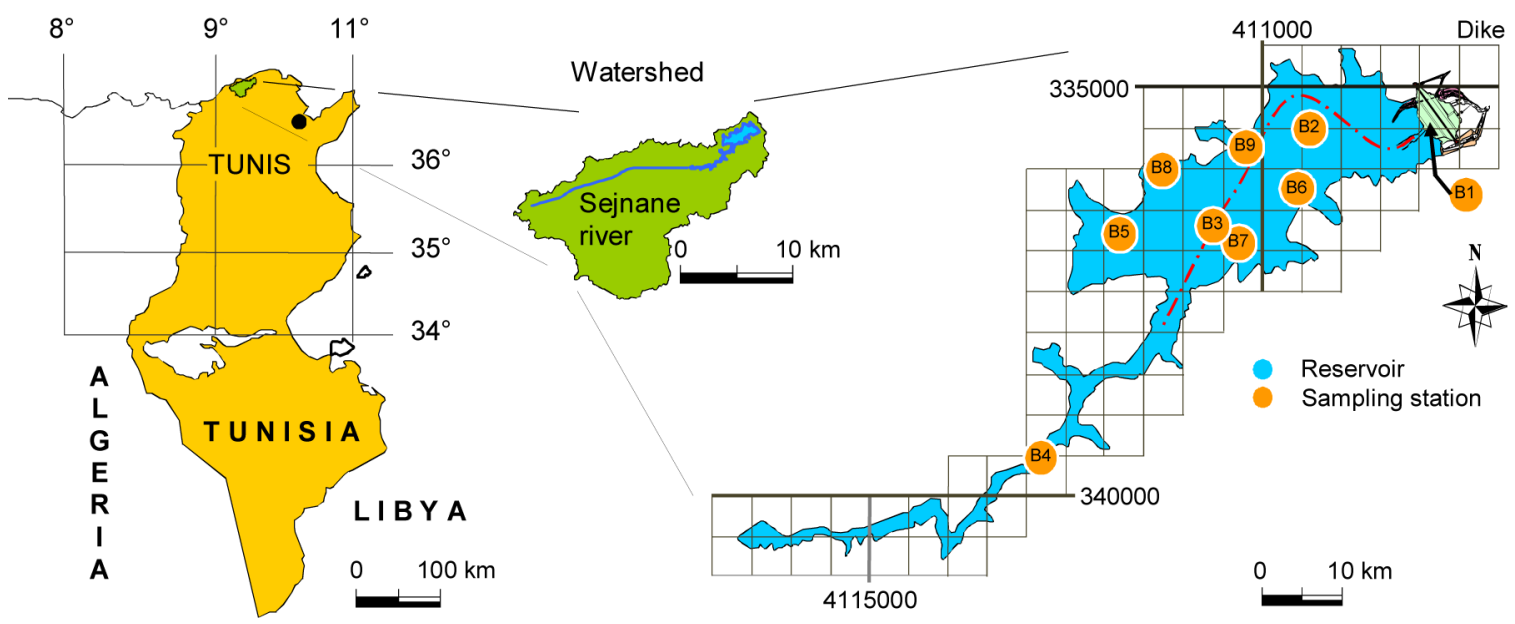

Fig. 1. Map showing the study area and the location of sampling stations in the Sejnane reservoir

of the Sejnane River and has been impounded since 1994 to provide water for drinking and irrigation.

The geology of the catchment includes Triassic to Quaternary deposits. The Sejnane region is dominantly a succession of reddish sandstone and silty clays (Crampon 1971). Each sandstone horizon is approximately $100 \mathrm{~m}$ thick and consists of fine to mediumgrained sand with some lenses of coarse conglomerate (25-30 $\mathrm{cm}$ in diameter). The interbedded argillaceous layers are generally greenish to greyish in colour and about $30 \mathrm{~cm}$ thick (Castany 1953; Rouvier 1977).

\section{Materials and methods}

\section{Sampling and analysis}

The sampling duration of the Sejnane reservoir lasted from November 2001 to October 2011. Samples were taken monthly at 9 sites of collection (B1 to B9 stations), which cover most of the surface area (Figure 1). Transparency readings were performed in situ with a $20 \mathrm{~cm}$ Secchi disk (SD). Samples for dissolved oxygen (DO) determination were taken from 2-metre vertical intervals in plain glass bottles by using the acid modification of the Winkler method (APHA 1976). Nutrient concentrations $(\mathrm{P}, \mathrm{N})$ and turbidity were measured from water samples taken at $5 \mathrm{~m}$ vertical intervals. In order to prevent biological decomposition, chloroform $0.5 \%$ was added to the samples. However, separate samples for Chlorophyll $a(\mathrm{Chl} a)$ were taken at multiple intervals of 2 and 5 metres. The water samples were stored in an appropriate packing material and transported in a dark cooler. Upon receipt in the laboratory, each water sample for nutrient analyses was filtered through $0.45 \mu \mathrm{m}$ Whatman GF/F glassfibre filters. Turbidity measurements (expressed in Nephelometric Turbidity Unit, NTU) were performed using a HACH 2100P turbidimeter. Chlorophyll $a$ was extracted in $25 \mathrm{ml} 90 \%$ ethanol and its concentration was determined by the colorimetric method (Lorenzen 1967). Samples for nutrient analyses were stored in the dark at $4^{\circ} \mathrm{C}$ before being analysed within two days following the AFNOR standard methods (1994). Nitrogen was analysed as nitrate $\left(\mathrm{NO}_{3}{ }^{-}\right)$, nitrite $\left(\mathrm{NO}_{2}^{-}\right)$ and ammonium $\left(\mathrm{NH}_{4}^{+}\right)$, phosphorus was analysed as total phosphorus (TP) and ortho-phosphorus $\left(\mathrm{PO}_{4}{ }^{=}\right)$. The climatic and hydrologic data, such as precipitation, inflows and outflows, were obtained from the archives of the Ministry of Agriculture.

\section{Data treatment}

The residence time of the reservoir was estimated by dividing the water volume by the discharge at the outlet expressed in million cubic metres. In a bounded system, this time is often approximated by the flushing time $\left(\mathrm{TF}=\mathrm{V} / \mathrm{Q}_{0}\right)$ (Straškraba et al. 1995; George and Hurley 2003), where $V$ and $Q_{O}$ are, respectively, the volume of stored water in the reservoir and the daily volumetric outflow rate.

The rank of a hydrosystem trophic state is often assessed by measuring several criteria such as nutrient abundance, column water transparency, phytoplankton growth, etc. None of these criteria was a direct measure of trophic state per se, but rather acted as indicators of it (Carlson 1977; OECD 1982). This is why we tried an array of different methods to assess the productivity of the Sejnane reservoir. The Troph- 
ic State Index (TSI) of Carlson (1977) incorporates monthly mean TP, SD and epilimnetic Chl $a$ in the entire reservoir into scores ranging from 0 to 100 with each 10-unit increase representing a doubling in algal biomass. For TSI the following equations were used:

TSI $($ Chl $a)=9.81 \ln [$ Chlorophyll $a(\mu \mathrm{g} / \mathrm{l})]+30.6$

TSI $(\mathrm{TP})=14.42 \ln [$ Total phosphorus $(\mu \mathrm{g} / \mathrm{l})]+4.15$

$\mathrm{TSI}(\mathrm{SD})=60-14.41 \mathrm{ln}$ [Secchi disk (metres)]

Where TSI(Chl $a$, TP and SD) and ln represent the individual Carlson trophic state indices and natural logarithm.

The strict boundary value between the trophic ranges is often unclear and undetermined with accuracy. Vollenweider (OECD 1982) developed a probabilistic approach that recognizes the uncertainty of the trophic designations and assesses the trophic state as a probability. In this model, the reservoir can be classified as ultra-oligotrophic, oligotrophic, mesotrophic, eutrophic or hypertrophic based on the probability distributions of mean concentrations of TP and Chl $a$ measured during the growing season and annual mean of SD in the water body (OECD 1982). The fixed boundary systems of the OECD (1982) and of Nürnberg (1996) state that the allocation of a given lake or reservoir to a trophic category should not be based only on one or three parameters as suggested by previous models, but on the total available information, such as Chl $a$ peak, minimum SD, annual mean of to- tal nitrogen (TN) and dissolved oxygen depletion rate. In order to synthesize the primary key relationships between different parameters, a multivariate technique such as Principal Component Analysis (PCA) was performed using the XLStat add-in program (Addinsoft 2012). The data introduced to run the PCA are structured in a matrix of 11 individuals (years of monitoring) and 10 variables which include nutrients (total phosphorus, ortho-phosphorus, total nitrogen and dissolved inorganic nitrogen), $\mathrm{N}$ to $\mathrm{P}$ ratio, Chl $a$, Secchi transparency, turbidity, residence time and precipitation with approximately more than 232 single observations each. As the participation of these parameters on the overall variability of the system is not known in advance, the standard deviation and the correlation of Pearson $(n)$ were used as proposed by Chatfield and Collin (1980), and Davis (1986).

\section{Results}

\section{Water inflows and residence time}

Water inflows show significant pulses with a wet season lasting from September to April, which accounted for more than $90 \%$ of annual flow, and a dry season for the rest of the year. The seasonal patterns of the daily water level are opposite to that of the daily residence time (Fig. 2). The residence time of waters shows a striking variation ranging from a few days

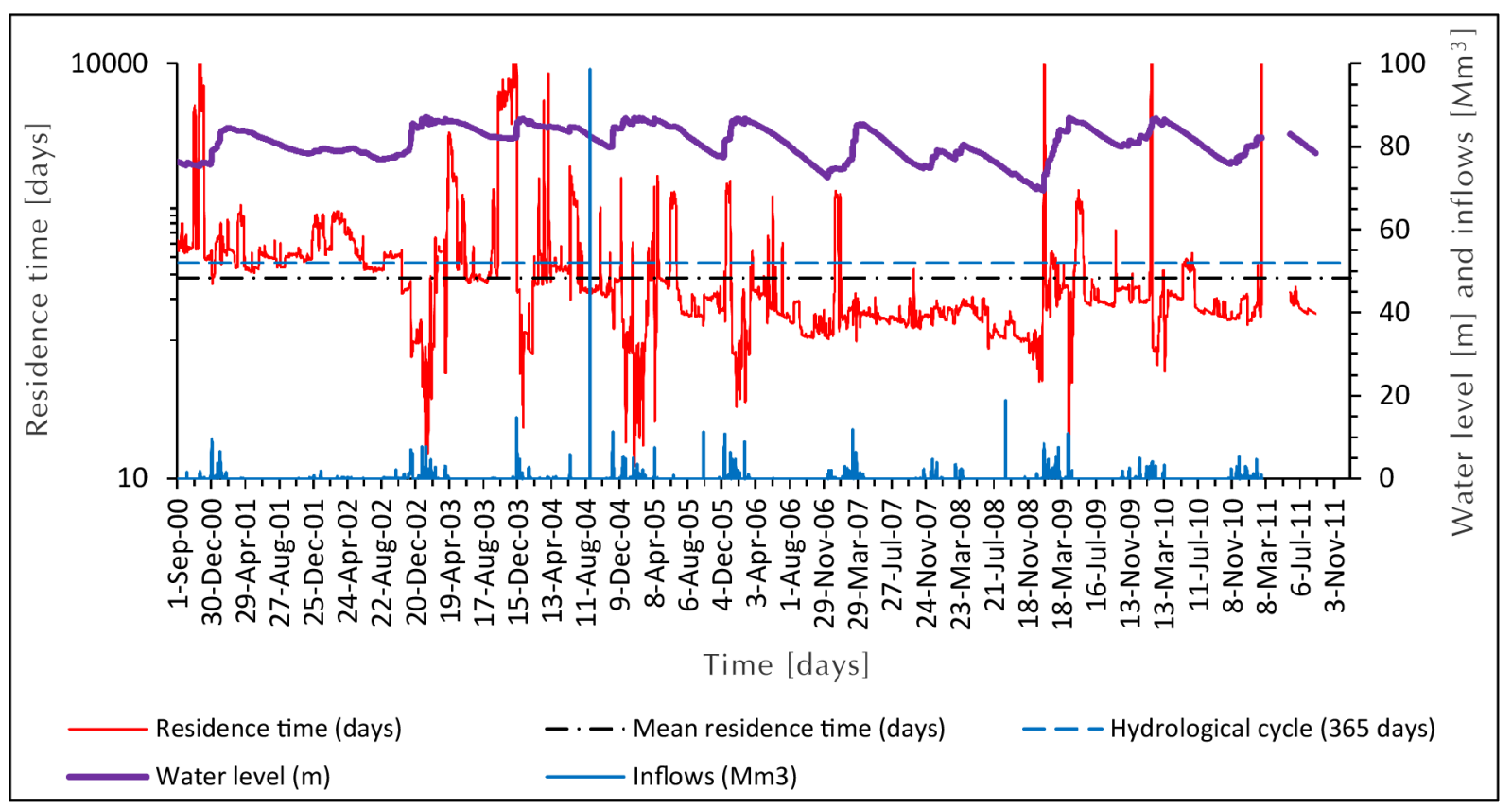

Fig. 2. Variations of inflows, water level and residence time in the Sejnane reservoir during the period 2001-2011 
(12 days) in the dry season to 10,000 days during the high flow season. Indeed, the intent of the widespread flood-operation is to preserve public properties on the downstream side of the dam by reducing the outflows. The residence time of the reservoir is 285 days on average, which reflects a relatively slow renewal of waters. Such residence time promotes, theoretically, complete cleaning of the reservoir during the current cycle. Following the classification of Straškraba and Tundisi (1999), the Sejnane reservoir appears to be considered an intermediate thermal stratified system.

\section{Water oxygenation, nutrients and chlorophyll a}

Waters are homogenous and well oxygenated during winter and spring (9-12.6 $\mathrm{mg} \mathrm{dm}^{-3}$; Fig. 3a). By late spring to early summer, the upper part of the water column is always sufficiently oxygenated, whereas in the bottom waters, the dissolved oxygen levels steadily decline to reach 1-4 $\mathrm{mg} \mathrm{dm}^{-3}$ and the oxycline extends from approximately $10 \mathrm{~m}$ down to $20 \mathrm{~m}$ depth. Near the water-sediment interface, where the decomposition of organic matter is active (Talling and Lemoalle 1998), DO tends sometimes to reach zero (0.1 $\mathrm{mg} \mathrm{dm}^{-3}$ ) during strong thermal stratification, which announces anoxic hypolimnetic conditions (Richards 2009; Wannamaker and Rice 2000).

Waters show sometimes high contents of total phosphorus with respect to the aquatic guideline of 0.1 $\mathrm{mg} \mathrm{dm}{ }^{-3}$ (US EPA 1983). Values range from 0.01 to 0.814 $\mathrm{mg} \mathrm{dm}{ }^{-3}$ with an average of $0.1 \mathrm{mg} \mathrm{dm}^{-3}$. Levels of orthophosphorus, a form of phosphorus that can be directly assimilated by plants and algae, are low (0.002-0.05 mg $\mathrm{dm}^{-3}$ ) and represent from 0 to $96 \%$ of TP (Fig. 3b).

The total nitrogen concentrations range from 0.01 to $7 \mathrm{mg} \mathrm{dm}^{-3}$ and show a significant variation over time and space (Fig. 3c). Surface waters and downstream waters are often richer in TN than those at the bottom and at the upstream with maximum gradients of 2.7 and $2 \mathrm{mg} \mathrm{dm}^{-3}$ respectively. The dissolved inorganic nitrogen (DIN) concentrations remain less than $7 \mathrm{mg} \mathrm{dm}^{-3}$ during the period of monitoring (Fig. 3d). Nitrates constitute the major part of DIN and vary between 0.1 and $4 \mathrm{mg} \mathrm{dm}^{-3}$. The highest concentrations were recorded mostly in wet seasons (1-4 $\mathrm{mg} \mathrm{dm}^{-3}$ ). During late-summer stratification, ortho-phosphorus and nitrate levels show a slight increase attributed to the sediment release and degradation of organic matter mainly in the anoxic bottom waters $\left(0-1.5 \mathrm{mg} \mathrm{dm}^{-3}\right.$ of DO). The long-term trend in nutrient concentrations indicates a slight decrease but it is not statistically significant $(\mathrm{r} \leq 0.2)$. The $\mathrm{N}$ to $\mathrm{P}$ ratio of Redfield (1958, 1963), Guildford and Hecky (2000), and Dzialowski et al. (2005), was calculated in the euphotic zone of 0-15 $\mathrm{m}$, where the biological activity of phytoplankton was favoured as well as at the reservoir bottom. The $\mathrm{N}$ to $P$ ratio shows large fluctuations in time and according to the depth (Fig. 3e). At normal operating conditions of the reservoir, values are in general greater than 8 and range from 20 to 200 with a mean of 104.6 , which suggests that the Sejnane reservoir is not conducive to an excessive algal development due to phosphorus limitation as mean $\mathrm{N}$ to $\mathrm{P}$ ratio is greater than 29. Overall and apart from some high levels in Chl $a$ concentration $\left(40 \mu \mathrm{g} \mathrm{dm}^{-3}\right)$ recorded during the growing seasons of May 2002 and June 2004, the mean values remain low in both surface and depth and do not exceed $10 \mu \mathrm{g} \mathrm{dm}^{-3}$ (Fig. 3f). The maximum values are often observed during spring and late summer to early fall when nutrients are more available. Surface waters (0-6 m) were on average 6 to 15 times richer in Chl $a$ compared to those in deep waters.

\section{Water clarity and euphotic zone}

Except 2002 where the reservoir was transparent with a mean turbidity value of 3.68 NTU over the entire water column (Fig. 4), during the rest of the period, waters were turbid and mean values were almost 20 NTU in summer and 45 NTU in winter due to the high erodibility of soils in the watershed (Khanfir 1984, 1989; Delaa 1995; Marzougui and Ben Mammou 2006), and dam desilting (292 NTU in February 2005).

On the surface, the turbidity generally varies between 0.4 and 40 NTU. However, to 5-10 m above sediments, it increases rapidly to reach excessive values (140-250 NTU) particularly along the main axis of the reservoir (B1 to B4 stations).

The Secchi disk transparency exhibits a weak downward trend over time $(r=0.23)$. Values vary between 0.15 and 3.6 with an average of $1.3 \mathrm{~m}$, which indicates a general low visibility of waters. Overall, the transparency increases from the upstream (B4 and B3 stations) to the downstream (B1 station). The lowest values of transparency were recorded in winter and spring $(0.15-1.6 \mathrm{~m})$ due to active mixing of waters and inflows. The depth of the euphotic zone (Zeu) calculated according to the equation of Dufour (1984), ranges from 0.38 to $9.21 \mathrm{~m}$ (Fig. 4). These results suggest that most of the chlorophyll biomass colonizes the top ten metres of the water column. 

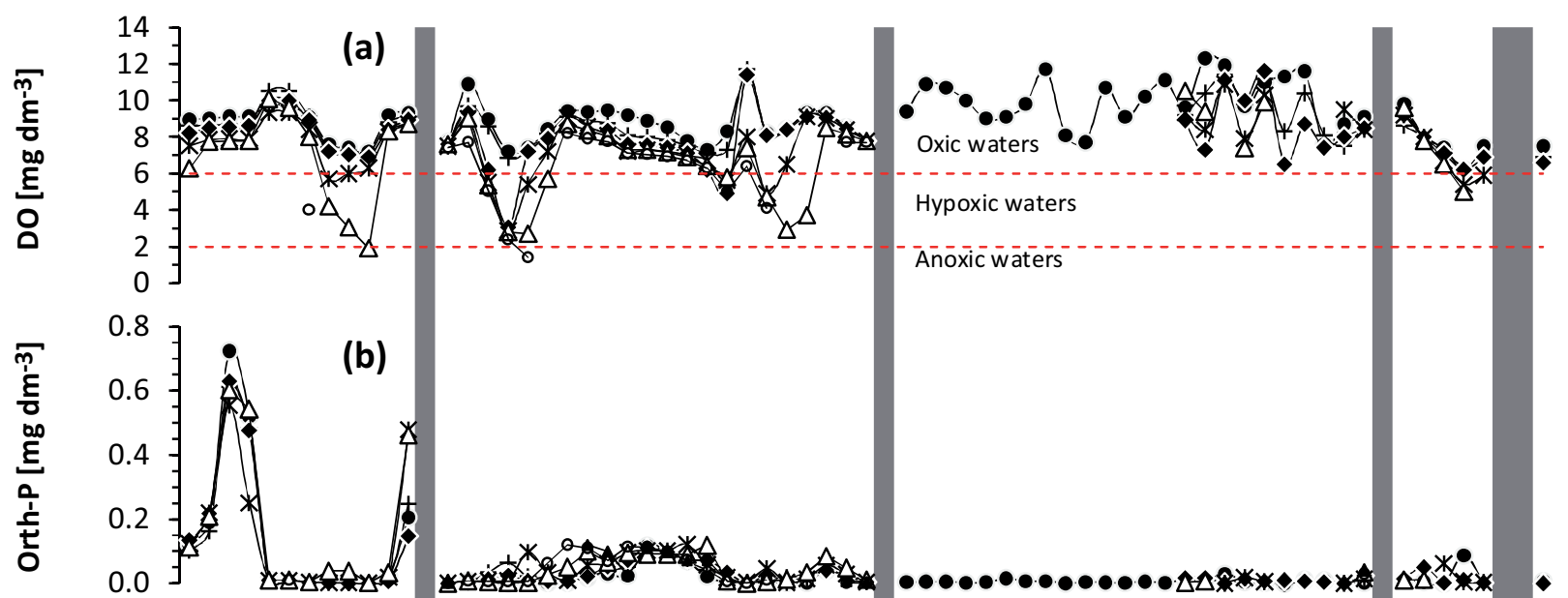

(b)
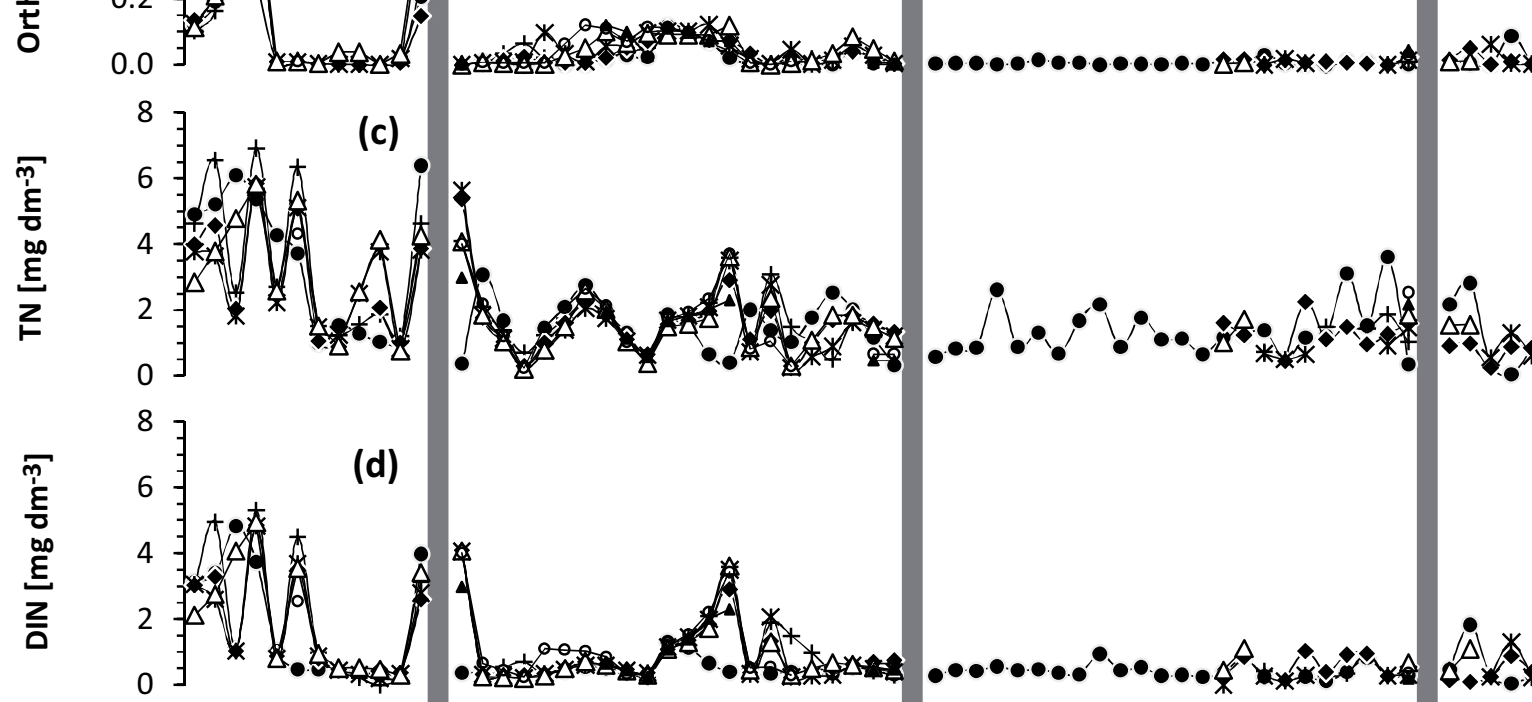

(d)
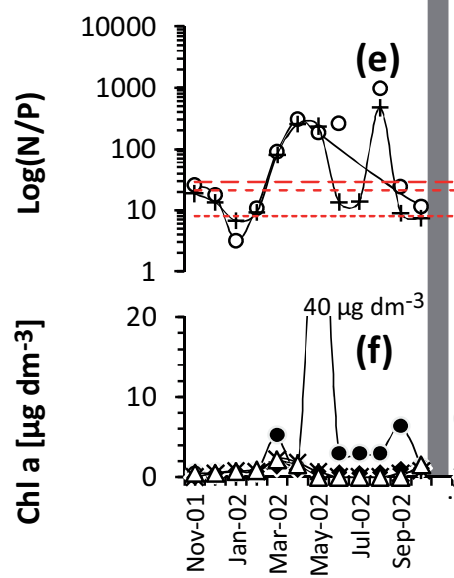

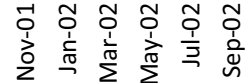
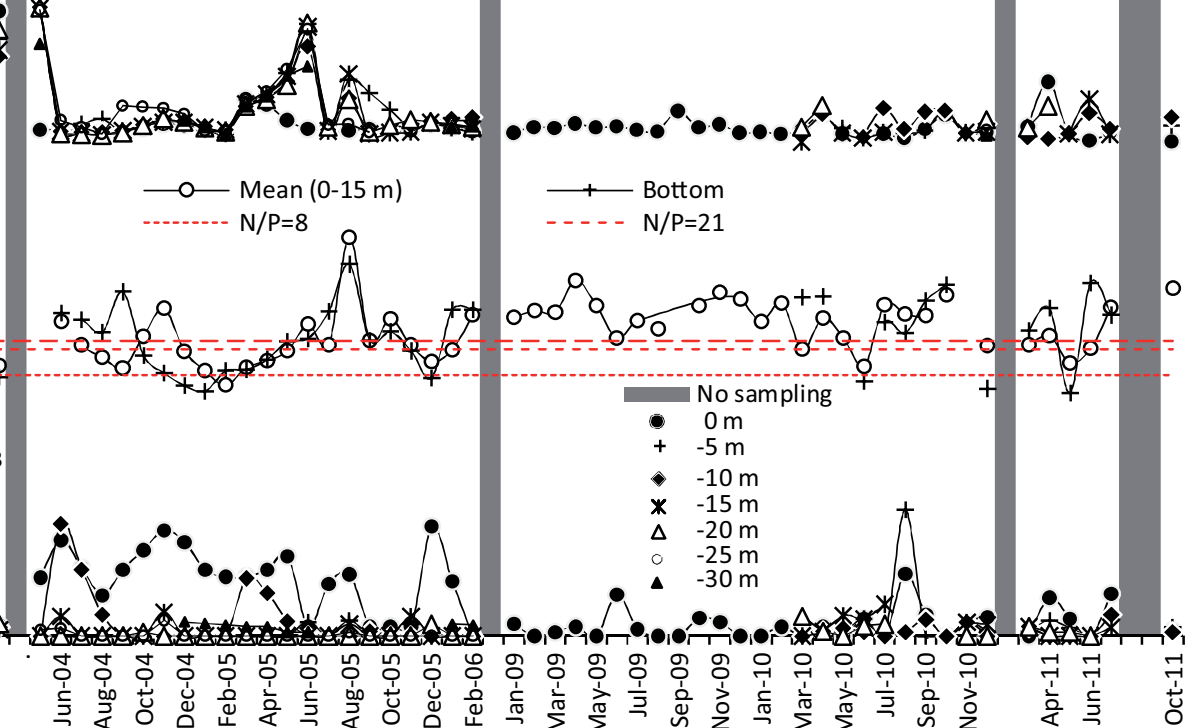

Time [month]

Fig. 3. Variations in dissolved oxygen (a), ortho-phosphorus (b), total nitrogen (c), dissolved inorganic nitrogen (d), N to P ratio e) and chlorophyll $a$ (f) at B1 station during the period 2001-2011 


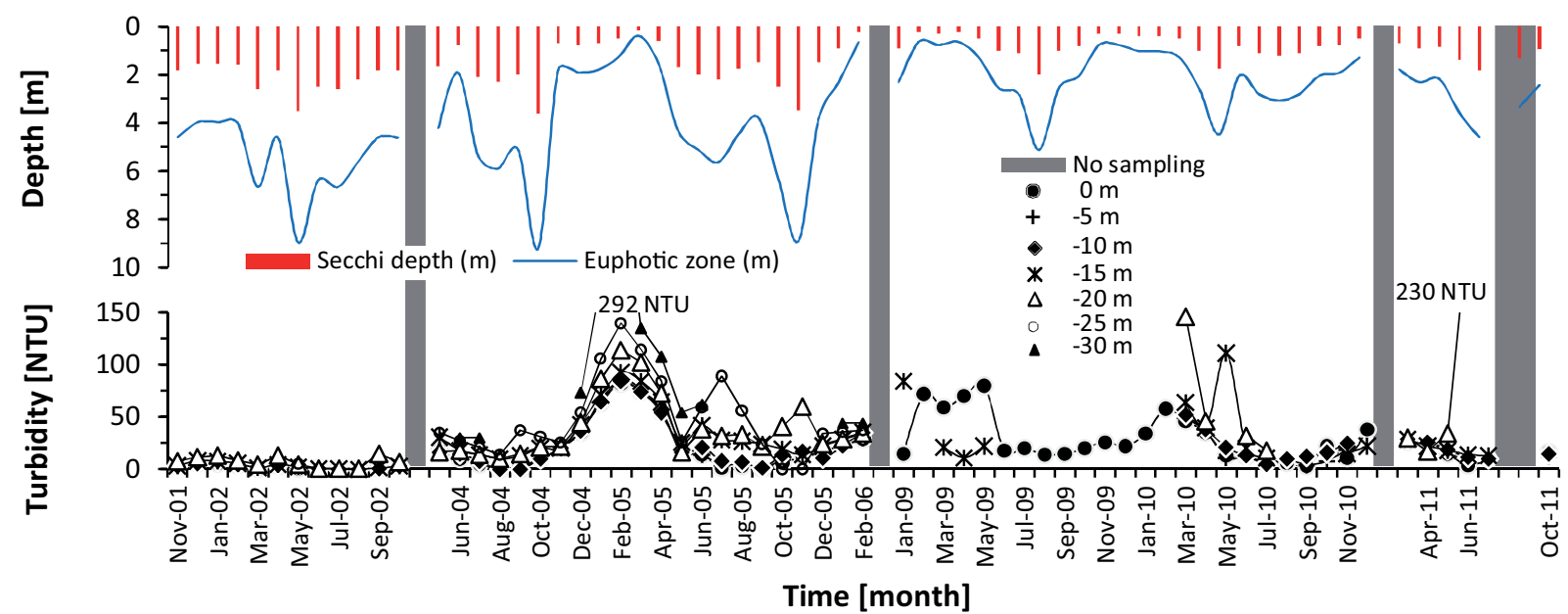

Fig. 4. Monthly variations of turbidity, Secchi transparency and euphotic zone in the Sejnane reservoir at B1 station during the period 2001-2011

Trophic state assessment

Carlson's index: The summer TSI(Chl a) (mean from June to August) varies between 34 and 49.3 with an average of 39.65 (Fig. 5). The trophic statue of the reservoir is oligotrophic in most regards (57\%) and to a lesser degree mesotrophic (23\%) for the considered period. The summer TSI(SD) ranges from 51 to 72 with an average of 57.2 and falls essentially in the eutrophic range (86\%). The spring TSI(TP) (mean from March to May) are relatively in excess; calculated values range between 49 and 76 . Waters are often eutrophic (86\%) more than hypertrophic (14\%). The global TSI index, determined by averaging the above elementary indices as stated by Carlson (1977), shows a stable annual variation ranging from 46 to 60 (Fig. 5). Hence, the reservoir is ranked mainly eutrophic to mesotrophic during the whole period of the test, which is in full concordance with the Secchi transparency index.

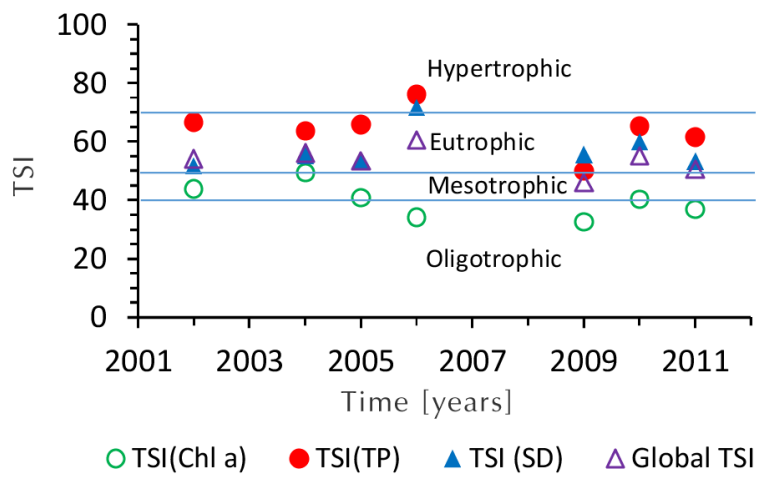

Fig. 5. Annual variations of the Carlson trophic index (1977), in the Sejnane reservoir based on chlorophyll $a$, total phosphorus and transparency during the period 2001-2011
The deviation values of TSI(Chl $a)$-TSI(SD) and TSI $(\mathrm{Chl} a)-\mathrm{TSI}(\mathrm{TP})$ are less than zero during the whole period of the record, which indicates that water visibility is mainly controlled by the predominance of smaller particles and TP surplus (Fig. 6). For 2006 and 2009 , scores plot near the diagonal line and indicate turbid situations (greater than 20 NTU on average), where Ortho-P can adsorb to surfaces of clay particles as demonstrated by the correlation between turbidity and ortho-phosphorus concentrations $(\mathrm{r}=-0.622)$. However, 2001 and to a lesser degree 2002 and 2005, plot so far from the diagonal because waters were clear with a large Secchi transparency (greater than 2 $\mathrm{m}$ ) and a low turbidity (less than 20 NTU).

Probability distribution diagrams of Vollenweider: The probability distribution of trophic range based on TP fluctuates significantly between years (Fig. 7). Values oscillate between hypertrophic (0-73\%, mean $19 \%)$, eutrophic (7-61\%, mean 35\%) and mesotrophic (1-64\%, mean 37\%). Considering the whole period of the test, waters have more chance to be mesotrophiceutrophic $(71 \%)$ rather than hypertrophic $(19 \%)$ or oligotrophic (9\%). Scores based on Chl $a$ vary from ultra-oligotrophic (0-92\%, mean 19\%) to eutrophic (0-39\%, mean 8\%), and are concentrated around oligotrophic (6-60\%, mean 38\%) to mesotrophic ranges (0-59\%, mean 35\%). One exception is 2001 , when eutrophic conditions were prevalent and the reservoir's water was more likely oligotrophic-mesotrophic (73\%) rather than ultra-oligotrophic and eutrophic. Secchi disk transparency was 77 to $100 \%$ indicating that the reservoir was hypertrophic-eutrophic over the sampling years. Mesotrophic range coincides with the dry 


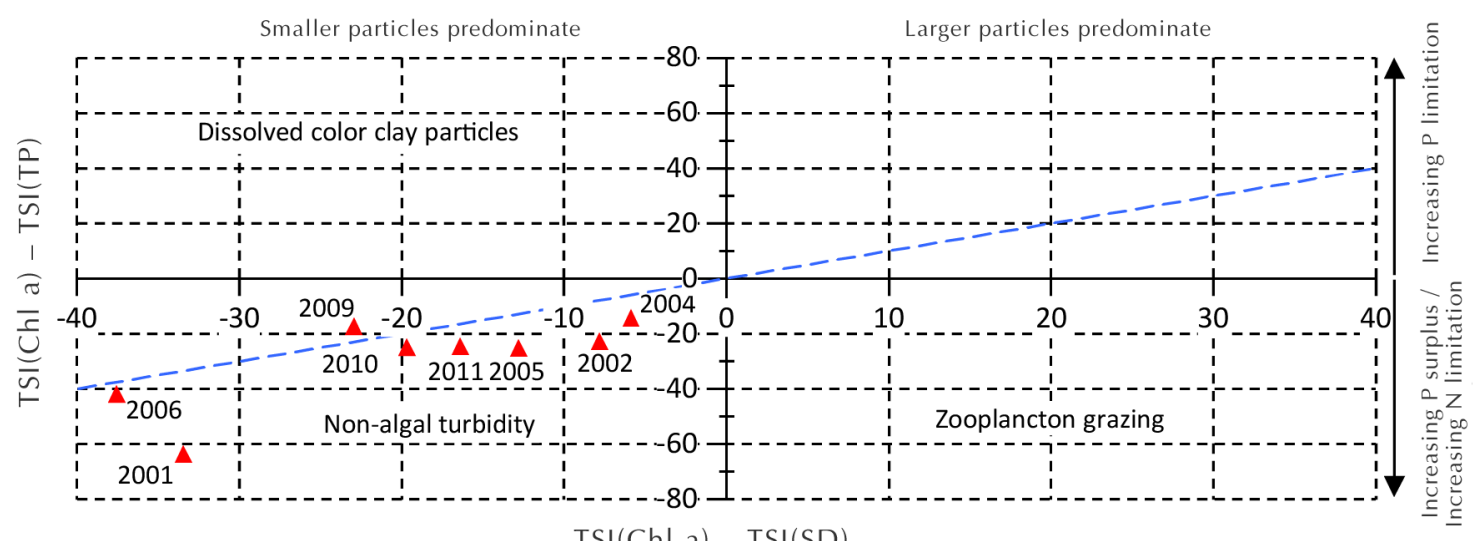

TSI(ChI a) - TSI(SD)

Fig. 6. Multivariate TSI comparison chart of the Sejnane reservoir during the period 2001-2011

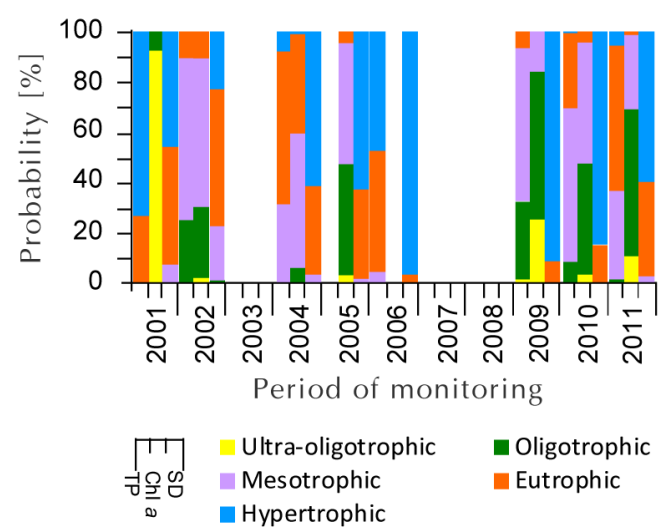

Fig. 7. Distribution of trophic levels of the Sejnane reservoir based on (a) annual mean total phosphorus, (b) chlorophyll $a$ and (c) transparency according to the OECD probabilistic model (1982) during the period 2001-2011

seasons 2001 and 2002, where it reaches a probability of 7 and $22 \%$ respectively and announces an improvement in water clarity.

Fixed boundary system of the OECD (1982): The system defines boundaries for annual means of total phosphorous, chlorophyll $a$, Secchi transparency, chlorophyll $a$ peak and Secchi transparency minimum. The TP levels evaluate the trophic status of Sejnane reservoir as eutrophic with a sharp trend to meso or hypertrophic ranges (Table 1), while levels of both Chl $a$ entries evaluate it essentially as being in the oligotrophic range, which can occasionally tend to the ultra-oligotrophic or mesotrophic range. However, SD entries rank the reservoir as frequently hypertrophic and rarely meso to eutrophic ranges despite the low productivity in the reservoir expressed by Chl $a$ entries. This may mean that waters are primarily transparency limited.
Fixed boundary system of Nürnberg: The fixed boundary system of Nürnberg (1996) defines boundaries for annual means of TP, TN, Chl $a$, Secchi transparency and $\mathrm{O}_{2}$ depletion rate. The oxygen depletion rate was calculated as a monthly regression of bottom water DO $\left(\mathrm{mg} \mathrm{dm}^{-3}\right)$ divided by the pond surface area $\left(\mathrm{m}^{2}\right)$ at the mid-level of water vs. time for the period of stratification (days). According to this system, TP concentration classifies the reservoir as mesotrophichypertrophic mainly eutrophic (Table 2). However, the TN and to a lesser degree the areal hypolimnic oxygen depletion rate rank it essentially as oligotrophic, which is in concordance with $\mathrm{Chl} a$ classification. Secchi transparency measurements evaluate the reservoir predominantly in the eutrophic-hypertrophic range during most of the study period.

\section{Discussions}

The correlation circle on the F1 and F2 axes (Fig. 8) displays that SD and DIN parameters are

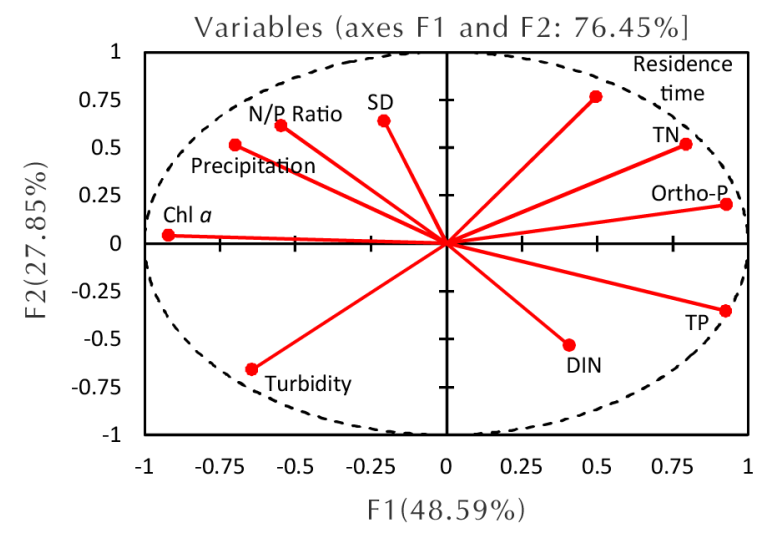

Fig. 8. Circle of correlation on the F1 and F2 axes 
Table 1. Trophic state of the Sejnane reservoir estimated according to the OECD fixed boundary system (OECD 1982), based on annual means of TP, Chl $a$ and Secchi depth, Peak of Chl $a$ and minimum of Secchi depth

\begin{tabular}{|c|c|c|c|c|c|}
\hline \multirow{2}{*}{ Trophic state category } & TP & Chl a & Peak Chl a & Secchi & Min. Secchi \\
\hline & {$\left[\mu \mathrm{g} \mathrm{dm}^{-3}\right]$} & {$\left[\mu \mathrm{g} \mathrm{dm}^{-3}\right]$} & {$\left[\mu \mathrm{g} \mathrm{dm}^{-3}\right]$} & {$[\mathrm{m}]$} & {$[\mathrm{m}]$} \\
\hline Ultra-oligotrophic UO & $\leq 4.0$ & $\leq 1.0$ & $\leq 2.5$ & $\geq 12.0$ & $\geq 6.0$ \\
\hline Oligotrophic O & $\leq 10.0$ & $\leq 2.5$ & $\leq 8.0$ & $\geq 6.0$ & $\geq 3.0$ \\
\hline Mesotrophic M & $10-35$ & $2.5-8$ & $8-25$ & $6-3$ & $3-1.5$ \\
\hline Eutrophic E & $35-100$ & $8-25$ & $25-75$ & $3-1.5$ & $1.5-0.7$ \\
\hline Hypertrophic H & $\geq 100$ & $\geq 25$ & $\geq 75$ & $\leq 1.5$ & $\leq 0.7$ \\
\hline \multirow[t]{2}{*}{2001} & 228.13 & 0.31 & 0.34 & 1.68 & 1.55 \\
\hline & $\mathrm{H}$ & UO & UO & $E$ & $\mathrm{M}$ \\
\hline \multirow[t]{2}{*}{2002} & 77.91 & 1.37 & 4.64 & 2.19 & 0.6 \\
\hline & $E$ & 0 & $\mathrm{O}$ & $E$ & $\mathrm{H}$ \\
\hline \multirow[t]{2}{*}{2004} & 32.7 & 7.22 & 33.5 & 1.40 & 0.25 \\
\hline & $\mathrm{M}$ & M & $E$ & $\mathrm{H}$ & $\mathrm{H}$ \\
\hline \multirow[t]{2}{*}{2005} & - & 4.03 & 14.07 & 1.14 & 0.15 \\
\hline & - & M & M & H & H \\
\hline \multirow[t]{2}{*}{2006} & 142.7 & 1.55 & 4.94 & 0.44 & 0.25 \\
\hline & $\mathrm{H}$ & $\mathrm{O}$ & $\mathrm{O}$ & $\mathrm{H}$ & $\mathrm{H}$ \\
\hline \multirow[t]{2}{*}{2009} & 19.6 & 1.12 & 5.2 & 0.66 & 0.25 \\
\hline & $M$ & 0 & 0 & $\mathrm{H}$ & $\mathrm{H}$ \\
\hline \multirow[t]{2}{*}{2010} & 46.8 & 1.57 & 8 & 0.85 & 0.40 \\
\hline & $E$ & 0 & 0 & $\mathrm{H}$ & $\mathrm{H}$ \\
\hline \multirow[t]{2}{*}{2011} & 47.3 & 1.37 & 3.03 & 1.00 & 0.7 \\
\hline & $\mathrm{E}$ & 0 & 0 & $\mathrm{H}$ & $\mathrm{H}$ \\
\hline Sum of categories & $3 \mathrm{E} 2 \mathrm{M} 2 \mathrm{H}$ & 502M1UO & 501E1M1UO & $6 \mathrm{H} 2 \mathrm{E}$ & $7 \mathrm{H} 1 \mathrm{M}$ \\
\hline
\end{tabular}

Table 2. Trophic state of the Sejnane reservoir estimated according to the model of Nürnberg (1996) based on annual means of TP, TN, Chl $a$, Secchi depth and summer areal hypolimnetic oxygen depletion rate

\begin{tabular}{|c|c|c|c|c|c|}
\hline \multirow{2}{*}{ Trophic state category } & TP & TN & $\mathrm{Chl} \mathrm{a}$ & Secchi & $\mathrm{O}_{2}$ depletion rate \\
\hline & {$\left[\mu \mathrm{g} \mathrm{dm}^{-3}\right]$} & {$\left[\mu \mathrm{g} \mathrm{dm}^{-3}\right]$} & {$\left[\mu \mathrm{g} \mathrm{dm}^{-3}\right]$} & {$[\mathrm{m}]$} & {$\left[\mathrm{mg} \mathrm{m}^{-2} \mathrm{~d}^{-1}\right]$} \\
\hline Oligotrophic O & $<10$ & $<350$ & $<3.5$ & $>4$ & $<250$ \\
\hline Mesotrophic M & $10-30$ & $350-650$ & $3.5-9$ & $4-2$ & $250-400$ \\
\hline Eutrophic E & $30-100$ & $650-1200$ & $9-25$ & $2-1$ & $400-550$ \\
\hline Hypertrophic H & $>100$ & $>1200$ & $>25$ & $<1$ & $>550$ \\
\hline \multirow[t]{2}{*}{2001} & 228.13 & 438 & 0.31 & 1.68 & - \\
\hline & $\mathrm{H}$ & $\mathrm{M}$ & 0 & $E$ & - \\
\hline \multirow[t]{2}{*}{2002} & 77.91 & 166 & 1.37 & 2.19 & 486 \\
\hline & $E$ & $\mathrm{O}$ & 0 & M & $E$ \\
\hline \multirow[t]{2}{*}{2004} & 32.7 & 135 & 7.22 & 1.40 & 288 \\
\hline & $E$ & $\mathrm{O}$ & $M$ & $E$ & M \\
\hline \multirow[t]{2}{*}{2005} & - & 88 & 4.03 & 1.14 & 104 \\
\hline & - & $\mathrm{O}$ & $\mathrm{M}$ & $E$ & $\mathrm{O}$ \\
\hline \multirow[t]{2}{*}{2006} & 142.7 & 57 & 1.55 & 0.44 & 304 \\
\hline & $\mathrm{H}$ & $\mathrm{O}$ & 0 & $\mathrm{H}$ & M \\
\hline \multirow[t]{2}{*}{2009} & 19.6 & 128 & 1.12 & 0.66 & 138 \\
\hline & $\mathrm{M}$ & $\mathrm{O}$ & 0 & $\mathrm{H}$ & 0 \\
\hline \multirow[t]{2}{*}{2010} & 46.8 & 117 & 1.57 & 0.85 & 169 \\
\hline & $E$ & $\mathrm{O}$ & 0 & $\mathrm{H}$ & $\mathrm{O}$ \\
\hline \multirow[t]{2}{*}{2011} & 47.3 & 121 & 1.37 & 1.00 & 100 \\
\hline & $\mathrm{E}$ & $\mathrm{O}$ & 0 & $\mathrm{E}$ to $\mathrm{H}$ & 0 \\
\hline Sum of categories & 4E2H1M & $701 \mathrm{M}$ & $602 \mathrm{M}$ & 3.5E3.5H1M & 402M1E \\
\hline
\end{tabular}


closer to the centre and, consequently, they participate somewhat in the overall variability of the system. The rest of the parameters are far from the centre and they constitute a homogeneous population in which all used variables are strongly interdependent and equitably important. The F1 axis explains the response of algal biomass (chlorophyll $a$ ) to nutrient availability (TP, Ortho-P and TN), along with the squared cosines which are more than 0.63 . However, the F2 axis defines clarity and renewal of waters (squared cosines greater than 0.436 ) and to a lesser degree the $\mathrm{N} / \mathrm{P}$ ratio (squared cosine $=0.377$ ).

The precipitation has a squared cosine of 0.5 between the F1 and F2 axes and seems to play a key role in the water quality changes (Zouabi Aloui and Gueddari 2009). The inverse relationship between Chl $a$ and nutrients, in particular with Ortho- $\mathrm{P}(\mathrm{r}=-0.9)$, is due to their assimilation by phytoplankton that promotes Chl $a$ growth to the detriment of phosphorus and nitrogen (Table 3 ). The lack of any correlation above the statistically significant threshold between DIN and Chl $a$, and between DIN and Ortho-P may be due to the diffusion rate of nitrogen at the air-water interface and the equilibrium between different phases of nitrogen in the reservoir (nitrification/denitrification, ammonification ...).

Residence time is orthogonal to annual precipitation (squared cosine $\approx 0$ ), which implies that the renewal of waters depends mainly on hydraulic management of the reservoir contrarily to what can occur in natural lakes. Moreover, the residence time was inversely and strongly correlated to turbidity $(\mathrm{r}=-0.82)$, due to inflow regime and sedimentation rate of clay particles. The residence time increases in response either to a decrease in outflows or to an increase in in- flows or to both. As transparency of waters is usually improved during the dry season, the inverse correlation between residence time and turbidity may be owing to the very short filling of the reservoir (few days) compared to its renewal, which takes 9 to 10 months (285 days on average).

In addition, the negative correlation primarily between precipitation and TP $(\mathrm{r}=-0.824)$ and secondarily between the other forms of nutrients $(r \leq-0.442)$ may be attributed to the dilution of waters by surface runoff. $\mathrm{Chl} a$ is moderately correlated to precipitation $(\mathrm{r}=0.586)$ and turbidity $(\mathrm{r}=0.513)$ indicating that the algal biomass development may depend on the regime of inflows that provides the reservoir with nutrients and controls the clarity of the water column. The negative correlation between turbidity and Ortho-P ( $\mathrm{r}=-0.622)$, may be due to the adsorption of phosphate by soil colloids.

The biplot of variables and individuals based on the F1 and F2 axes (Fig. 9) reveals that most of the hydrological cycles (more than 63\%) are strongly

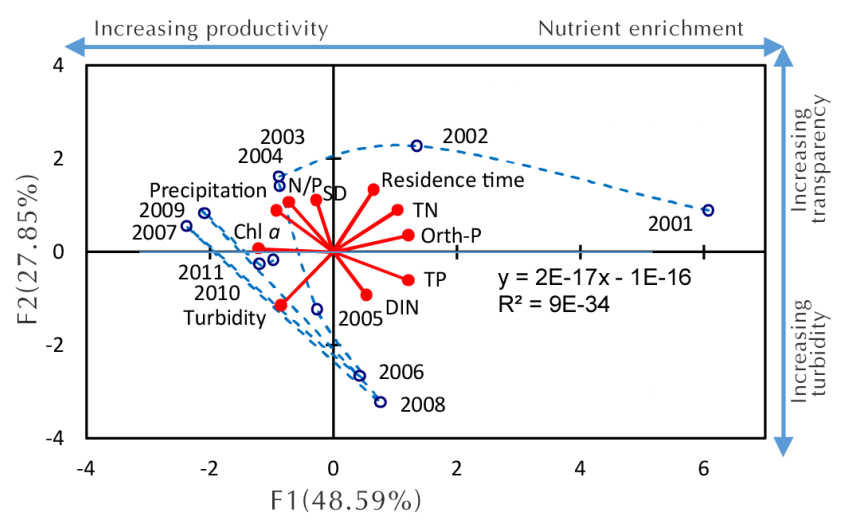

Fig. 9. Biplot of variables and observations showing the trophic trend of the Sejnane reservoir during the period 2001-2011

Table 3. Pearson correlation matrix of selected water quality variables of Sejnane reservoir

\begin{tabular}{|c|c|c|c|c|c|c|c|c|c|c|c|}
\hline & $n$ & TP & Orth-P & $\mathrm{TN}$ & DIN & Chl a & SD & Turb & $\mathrm{N} / \mathrm{P}$ & RT & $\mathrm{P}$ \\
\hline $\mathrm{TP}\left[\mathrm{mg} \mathrm{dm}^{-3}\right]$ & \multirow{10}{*}{232} & 1 & & & & & & & & & \\
\hline Orth-P [mg dm$\left.{ }^{-3}\right]$ & & 0.781 & 1 & & & & & & & & \\
\hline $\mathrm{TN}\left[\mathrm{mg} \mathrm{dm}^{-3}\right]$ & & 0.544 & 0.922 & 1 & & & & & & & \\
\hline DIN [mg dm-3] & & 0.566 & 0.272 & -0.070 & 1 & & & & & & \\
\hline $\mathrm{Chl} a\left[\mu \mathrm{g} \mathrm{dm}^{-3}\right]$ & & -0.860 & -0.900 & -0.807 & -0.250 & 1 & & & & & \\
\hline $\mathrm{SD}[\mathrm{m}]$ & & -0.423 & -0.178 & -0.031 & -0.165 & 0.485 & 1 & & & & \\
\hline Turb [NTU] & & -0.368 & -0.622 & -0.767 & 0.129 & 0.513 & -0.451 & 1 & & & \\
\hline N/P & & -0.720 & -0.297 & 0.017 & -0.667 & 0.331 & 0.108 & 0.072 & 1 & & \\
\hline RT [days] & & 0.202 & 0.592 & 0.704 & 0.057 & -0.319 & 0.551 & -0.821 & 0.100 & 1 & \\
\hline $\mathrm{P}\left[\mathrm{mm} \mathrm{yr}^{-1}\right]$ & & -0.824 & -0.442 & -0.221 & -0.399 & 0.586 & 0.292 & 0.262 & 0.834 & 0.081 & 1 \\
\hline
\end{tabular}


linked to annual precipitation, $\mathrm{N}$ to $\mathrm{P}$ ratio and Secchi disk transparency. Three scenarios may be mentioned in the Sejnane region. The first expresses the group of relatively productive and wet years with transparent waters, i.e. 2003 and 2004, a second group of low productivity and dry years with transparent waters, i.e. 2001 and 2002, and a third group of moderate productivity and turbid waters, i.e. 2006 and 2008. The low correlation coefficient between the observations (hydrological cycles) and the F1 axis over a decade of monitoring $\left(\mathrm{R}^{2} \approx 0\right)$ suggests the lack of any significant long-term trend of productivity in the reservoir, which shows several fluctuations in time depending on inflow regime, nutrients and water transparency (Figs 2 and 4).

Elementary indices used by Carlson (1977) to evaluate productivity are slightly stable, close to each other and ranged mostly between mesotrophic and eutrophic states. This is due, on the one hand, to logarithmic scale, which reduces wide-ranging quantities to smaller scopes and, on the other hand, to the fact that the model uses values from the same period where the measured parameter is at its maximum value, which reduces the effects of contrasted and irregular climate.

The TSI(Ortho-P) values are closer to the biological index TSI $(\mathrm{Chl} a)$ than those computed based on $\mathrm{TP}$ due to poor mineralization during spring. The high values of TSI(SD) are due to the relatively excessive sedimentary turbidity in the water body (20-45 NTU).

On the whole, TSI(TP) and TSI(SD) values compare favourably to each other. However, the TSI levels for Chl $a$ were significantly lower than the other TSI values (Fig. 5). This indicates that algal development is not only phosphorus limited, but also disfavoured by turbidity.

The difference between global and elementary trophic state indices lies between 20 and 39 recorded in 2004 and 2002 respectively. This implies that one selected index, and possibly more, is not a good predictor of the trophic state in the reservoir. The calculation of the global trophic index by averaging elementary TSIs may give an inaccurate estimation (Carlson and Simpson 1996). As the index is an expression of productivity (algal biomass), chlorophyll $a$ is the better predictor than either of the other two indices (Carlson 1977).

$\mathrm{TP}$ and to a lesser degree SD measurements generally predict higher levels of productivity compared to the Chl $a$ parameter due to sedimentary turbidity, which contributes to decreasing water clarity and promotes the adsorption of phosphorus into soil particles, which decreases, indirectly, the bioavailability of phosphorus. Also, the relatively long residence time of waters (9-10 months) supports the restitution of phosphorus in the sediment that can be released when anoxic conditions are prevalent (Kröger et al. 2012). Regarding previous observations, TP would be omitted as a trophic status indicator in the final TSI value since it is often abnormally high and not fully bioavailable. However, SD should continue to be a good estimator for the overall water quality of the reservoir as it is closely associated with the global trophic index.

According to the Vollenweider probabilistic model (OECD 1982), the productivity in the reservoir differs significantly between TP, Chl $a$ and SD predictors and changes from oligotrophic to hypertrophic (Figs 6-8), due to the irregular regime of inflows and phosphorus loading. As previously mentioned, the Secchi transparency predictor gives waters a high probability to be hypertrophic-eutrophic, while Chl $a$ gives them a high probability to be oligotrophic-mesotrophic. Besides, $\mathrm{Chl} a$ probabilities remain relatively steady in terms of dominant classes despite significant variations in the TP concentrations. This implies that water clarity is the primary factor limiting phytoplankton growth in the dam. Hence, SD should be omitted as a good predictor as it diverges too far away from Chl a prediction.

The fixed boundary system of the OECD (1982), classifies the reservoir most often in mesotrophic to hypertrophic ranges. Both annual mean and minimum Secchi transparency over-ranked the reservoir as hypertrophic essentially despite the low rate of productivity or the predisposition to promote it in the reservoir expressed respectively by chlorophyll $a$ entries and total phosphorus. What emerges from the fixed boundary system of the OECD (1982) led to the conclusion that algal growth is strongly limited by water column transparency.

In the fixed boundary system of Nürnberg (1996), both total phosphorus and Secchi transparency annual boundaries often over-ranked the reservoir as eutrophic to hypertrophic, which is not in concordance with $\mathrm{Chl} a$, total nitrogen and the areal hypolimnic oxygen depletion rate (Table 2). This implies a clear limitation of algal growth by transparency of the water column and phosphorus bioavailability. However, many similar turbid artificial lakes - such as Lake Krugersdrift in South Africa - experienced serious adverse effects of cyanobacteria (Walmsley et al. 1980; Allanson et al. 1990; Oberholster et al. 2013). 
As the sensitivity of the reservoir to light limitation remains poorly understood, special attention should be paid to the upper catchment in order to apply best management practices that can maintain the primary productivity at its lowest level. Decreased sediment siltation and phosphorus loads are possible, but trophic state may shift during low flow periods, once light limitation is removed (McDowell et al. 2004). In particular, managers should stabilize streambanks and prevent erosion, deforestation and land misuse.

\section{Conclusions}

The results presented and discussed above have yielded the following conclusions:

- The Sejnane reservoir has no excessive algal growth as indicated by chlorophyll $a$ mean concentrations, which remain less than $20 \mu \mathrm{g} \mathrm{dm}^{-3}$ in most of the period of the record.

- Based on chlorophyll $a$, the main criteria of productivity, the Sejnane reservoir commonly exhibits a mesotrophic condition, which may show sharp trends to oligotrophic or eutrophic depending on the model used. The moderately clear waters with limited summer hypolimnetic anoxia support exclusively oligotrophic to mesotrophic conditions.

- The sedimentary turbidity in the reservoir decreases water column clarity and promotes the adsorption of phosphorus to soil particles, which limits chlorophyll $a$ growth.

- For all tested models, total phosphorus and Secchi transparency parameters overestimate the productivity in the Sejnane reservoir. They would be omitted as good trophic state indicators respectively from all tested models and from fixed boundary systems since they are abnormally high compared to chlorophyll $a$.

With the exception of the Carlson index, the probabilistic model of Vollenweider (1982), and the fixed boundary systems of the OECD (1982) and of Nürnberg (1996) have some restrictions in interpreting the non-algal turbidity effects on biotic and abiotic water quality parameters.

The Nürnberg model (1996) and to a lesser degree the Carlson index, appear to be the most suitable methods for evaluating primary productivity in the Sejnane reservoir, since they provide a clear internal coherence between self-indicators and an accurate quantitative assessment of productivity.

\section{References}

Addinsoft, 2012, XLStat 2012 (Version 2012.5.01) [Computer software], Paris, France.

[AFNOR] Association Française de Normalisation , 1994, Qualité de l'eau, Environnement, Recueil des normes françaises, Paris, p. 861.

Allanson B.R., Hart R.C., O’Keeffe J.H., Robarts R.D. 1990, Inland waters of Southern Africa: an ecological perspective, Kluwer Academic Publishers, Dordrecht, p. 458.

[APHA] American Public Health Association, 1976, Standard methods for the examination of water and waste water, APHA-AWWA-WEF, New York, p. 1193.

Benzha F., Taoufik M., Dafir J. E., Kemmou S., Loukili L., 2005, Qualité physico-chimique des eaux du réservoir Daourat; impact de la vidange sur son fonctionnement, J. Water Sci.18: 57-74.

Carlson R.E., Simpson J., 1996, A coordinator's guide to volunteer lake monitoring methods, North American Lake Management Society, Madison, p. 96.

Carlson R.E., 1977, A trophic state index for lakes, Limnol. Oceanogr. 22: 361-369.

Carmichael W.W., 2001, Health effects of toxin-producing cyanobacteria: "The cyanoHABs", Hum. Ecol. Risk Assess. 7: 1393-1407.

Castany G., 1953, Le Tyrrhénien de la région de Bizerte, Bull. Soc. Sci. Nat. 6 : 1952-1953.

Chatfield C., Collin A.J., 1980, Introduction to Multivariate Analysis, Chapman \& Hall, London, p. 246.

Chorus I., Bartram J. (eds), 1999, Toxic Cyanobacteria in Water. A guide to their public health, consequences, monitoring and management, E \& FN Spon, London, p. 416.

Crampon N., 1971, Etude géologique de la bordure des Mogods, du pays de Bizerte et de Nord des Hédil. [thesis], Nancy, p. 522.

Davis J.C., 1986, Statistics and data analysis in geology, Viley, New York, p. 646.

Delaa A., 1995, Application de la télédétection et les systèmes d'information géographique à l'étude du fonctionnement hydrologique du bassin versant de l'Oued Sejnane [Thesis], FST, p. 130.

Dufour P., 1984, La biomasse des lagunes côtières. Exemple de la lagune Ébrié (Côte-d'Ivoire), Rev. Hydrobiol. Trop. 27: 207-233.

Dzialowski A.R.S.H., Wang N.C., Lim W.W., Spotts, Huggins D.G., 2005, Nutrient Limitation of Phytoplankton Growth in Central Plains Reservoirs, USA, J.Plankton Res. 27: 587-595.

George D.G., Hurley M.A., 2003, Using a continuous function for residence time to quantify the impact of climate change on the dynamics of thermally stratified lakes, J. Limnol. 62: 21-26.

Guildford S J., Hecky R.E., 2000, Total nitrogen, total phosphorus, and nutrient limitation in lakes and oceans: Is there a common relationship?, Limnol. Oceanogr. 45: 1213-1223. 
Jean A., Nejib R., 1997, Hill reservoirs in Tunisia: stakes, constraints and prospects, C.R. Acad. Agric. Fr. 83(2): 77-88.

Khanfir H.,1989, Etude géologique, hydrogéologique et géotechnique du Barrage de Sejnane [Thesis], U.F.R. Sc. Tech. Besançon, p. 245.

Krause P.,1984, Evolution de la situation trophique dans la retenue de Sidi Salem. Evolution of the trophic situation in the Sidi Salem reservoir, Ministry of Agriculture, Tunis.

Kröger R., Lizotte Jr, R.E. Shields Jr, F.D., Usborne E., 2012, Inundation influences on bioavailability of phosphorus in managed wetland sediments in agricultural landscapes, J. Environ. Qual. 41(2): 604-614.

Lars L., Ulf W., 1988, Eutrophication of lakes and reservoirs in warm climates, WHO Regional Office for Europe, Copenhagen, p. 134.

Lorenzen C.J., 1967, Determination of chlorophyll and phaeopigments: spectrophotometric equations. Limnol. Oceanogr. 12: 343-346.

Marzougui A., Ben Mammou A., 2006, Le barrage de l'Oued Sejnane: quantification de l'alluvionnement et évaluation de l'érosion spécifique de son bassin versant, GeoEco-Trop. 30: 57-68.

McDowell R.W., Biggs B.J.F., Sharpley A.N., Nguyen L., 2004, Connecting phosphorus loss from agricultural landscapes to surface water quality, Chem. Ecol. 20: 1-40.

Nürnberg G.K., 1996, Trophic state of clear and colored, soft- and hardwater lakes with special consideration of nutrients, anoxia, phytoplankton and fish, Lake Reserv. Manage. 12: 432-447.

Oberholster P.J., Dabrowdki J., Botha A.-M., 2013, Using modified multiple phosphorus sensitivity indices for mitigation and management of phosphorus loads on a catchment level, Fundam. Appl. Limnol. 182: 1-16.

OECD 1982, Eutrophication of Waters. Monitoring. Assessment and Control, OECD, Paris, p 156.
Redfield A.C., 1958, The biological control of chemical factors in the environment, Am. Sci. 46: 205-21.

Redfield A.C. Ketchum B.H., Richards F.A., 1963, The influence of organisms on the composition of sea water, [in :] Hill M.N. (ed.), The Sea: Vol. 2, Wiley, New York : 26-77.

Remini B., 2010, La problématique des eaux de l'Algérie du Nord, Larhyss Journal 8: 27-46.

Richards JG., 2009, Metabolic and molecular responses of fish to hypoxia, [in:] Richards J.G., Farrell A.P., Brauner C.J. (ed.), Hypoxia, Elsevier, San Diego: 443-485.

Rouvier H., 1977, Géologie de l'extrême-nord tunisien: tectoniques et paléogéographies superposées à l'extrêmité orientale de la chaîne nord-maghrébine [Thesis], Université Pierre et Marie Curie, Paris, p. 427.

Sternick K. H., 1991, Annuaires limnologiques relatifs à la trophie et l'eutrophisation du barrage Sidi Salem. Ministère de l'Agriculture, Tunisie, Direction générale des études des travaux hydrauliques-Deutsche Gesellschaft für Technische Zusammenarbeit (GTZ). Projet «protection et exploitation du barrage Sidi Salem», Tunis, p 43.

Straškraba M., Tundisi J.G., 1999, Guidelines of lake management: reservoir water quality management : Vol. 9, ILEC, Kusatsu, p. 229.

[US EPA] U.S. Environmental Protection Agency, 1983, Methods for chemical analysis of water and wastes, U.S. Environmental Protection Agency, Washington, p. 491.

Walmsley R.D., Butty M., Van Der Piepen H., Grobler D.C., 1980, Light penetration and the interrelationships between optical parameters in a turbid subtropical impoundment, Hydrobiologia 70:145-157.

Wannamaker C.M., Rice J.A., 2000, Effects of hypoxia on movements and behavior of selected estuarine organisms from the southeastern United States, J. Exp. Mar. Biol. Ecol. 249: 145-163.

Zouabi Aloui, B., Gueddari M., 2009, Long-Term water quality monitoring of the Sejnane reservoir in North East Tunisia, Bull. Eng. Geol. Env. 68: 307-316. 